J. Natn. Sci. Coun. Sri Lanka 198210 (2) : 181-194

\title{
Some Studies on the Reaction of Apatite with Soda Ash and Quartz
}

\author{
R. P. Gunawardane \\ Department of Chemistry, University of Peradeniya, Peradeniya, Sri Lanka.
}

(Date of receipt : 12 March 1982)

(Date of acceptance : 26 July 1982)

\begin{abstract}
The reaction of rock phosphate samples from Brazil, South Africa and Senegal with soda ash and quartz has been investigated for the prodiction of a phosphate fertilizer. In this study, compositions around the optimum molar ratio found for Eppawela apatite i.e. apatite, soda ash and quariz, 1:2:1 respectively have been used. The rock samples from Brazil (Jacupiranga) and South Africa (Phalaborwä) were found to be suitable while the Senegal sample (pallo) appeared to be unsuitable for the process. Quartz may be partly or completely replaced by potash feldspar ir the compositions with Eppawela apatice to produce potash containing phosphorus fertilizer. Effect of different atmospheres on the reaction as well as the results of Differential Thermal Analysis and Thermogravimetric Analysis are presented. The optimum temperature for the reaction was confirmed to be $900^{\circ} \mathrm{C}$. The determination of soluble choride by Mohr titration method at differentstages of the reaction of Eppawela apatite with soda ash and quartz indicates that the cinloride ion exchange occurs prior to the solid state reaciion leading to the formation of rhenaite, $\mathrm{CaNaPO}_{4}$, as the major phase.
\end{abstract}

\section{Introduction}

Phosphate rock apatite has the general formula ${ }^{3}$ close to $\mathrm{Ca}_{5}\left(\mathrm{PO}_{4}\right)_{3} \mathrm{X}$, where $\mathrm{X}$ can be $\mathrm{F}, \mathrm{Cl}$, OH or $1 / 2 \mathrm{CO}_{3}$. It is sparingly soluble and most of its phosphorus content is not available for plant nutrition. A number of commercial methods are available to convert this mineral to soluble phosphorus fertilizers. Most commonly, apatite is treated with strong acids such as sulphuric acid or phosphoric acid to produce superphosphate fertilizers. Alternative processes which use indigenous raw materials with lower investments are required specially for developing countries whlch do not produce strong acids.

With this in view, the solid state reaction of Sri Lanka apatite (from the deposit at Eppawela) with soda ash and quartz has been studied ${ }^{6},{ }^{7}$ to determine the optimum. conditions for the production of a fertilizer. The product developed was similar to Rhenania phosphate and was made by sintering apatite, sodium carbonate and quartz in the molar ratio of $1: 2: 1$ at $900^{\circ} \mathrm{C}$ for 2 hours. Almost $100 \%$ of its total phosphorus content is available for plant nutrition. This of course has yet to be confirmed by plant and pot trials. 
This method can be cmployed to produce a fertilizer when the rock is not suitable for direct acid treatment or for phosphoric acid production. The method may also be used in developing countries where sulphuric acid and phosphoric acid are not readily available. Therefore, it is of interest to study the application of this method to similar rock samples from other countries. Furthermore, in order to make the process simpler, commercially viable and also to reduce the reaction temperature and time it is also necessary to study the mechanism of the sintering reaction.

In the present study two aspects of the process have been investigated. Firstly, the reaction of three phosphate rock samples from Brazil, South Africa and Senegal with soda ash and quartz have been studied in the molar ratio of apatite, soda ash and quartz close to $1: 2: 1$ in order to examine the suitability of these rock samples for the process. Secondly, detailed investigation of the various stages of the reaction of Eppawela apatite with soda ash and quartz have been undertaken to understand the mechanism of the reaction.

\section{Experimental}

\subsection{Heating Experiments}

The batches were prepared by blending the rock samples (minus 100 mesh, B.S.), dried analar sodium carbonate and quartz (minus 120 mesh) and firing the mixture at appropriate temperatures in inuffle furnace using alumina crucibles. Heating experiments in a controlled gas atmosphere were carried out in a tube furnace containing two tubes. The tubes were about $30 \mathrm{~mm}$ diameter and typical gas flow rates were 100 c.c./min. After heat treatment, the samples were allowed to cool and the phases present were determined by powder X-ray diffraction using $\mathrm{Cu} \mathrm{K} \alpha$ radiation.

\subsection{DTA and TGA}

Differential thermal analyses of the samples were carried out using a Du Pont 900 Thermal Analyser and a Stanton Refcroft STA 780 Simultaneous Thermal Analyser. Thermogravimetric analyses were carried out using a Du Pont 950 Thermogravimetric Analyser.

\subsection{Extraction of Phosphorus}

Laboratory evaluation of phosphate content (in wt. $\% \mathrm{P}_{2} \mathrm{O}_{5}$ ) available for plant nutrition, is generally done by estimating either water soluble or citrate ${ }^{12}$ soluble $\mathrm{P}_{2} \mathrm{O}_{5}$. In the present study, available phosphorus content has been estimated by the $2 \%$ citric acid method. The samples were ground to pass through 100 mesh B.S. sieve. Approximately $1.0 \mathrm{~g}$ samples were extracted with $100 \mathrm{ml}$ of $2 \%$ citric acid using a mechanical shaker operating at about 260 oscillations per minute for 30 minutes. 
The total phosphorus content in the rock samples as well as other products were determined by extracting with a mixture of conc. $\mathrm{HCl}$ and conc. $\mathrm{HNO}_{3}$ followed by $65 \% \mathrm{HClO}_{4}$.

\subsection{Analysis for Phosphorus}

The phosphorus contents of the extracts were determined by the vanadomolybdate method $^{9}$ using a Unicam SP 600 colorimeter at a wave length of $460 \mathrm{~nm}$. To minimise errors due to interference by other species present in the solution, all the extracts and the standard phosphate solutions were made in $2 \%$ citric acid solution.

\section{Results and Discussion}

\subsection{Experiments with foreign rock samples}

The following three rock phosphate samples from Brazil, South Africa and Senegal have been investigated.

(I) Jacupiranga rock sample from Brazil (J. sample)

(II) Phalaborwa rock sample from South Africa (P. sample)

(III) Pallo rock sample from Senegal (S. sample)

\subsubsection{Data on the rock samples:}

Solubility data and the total $\mathrm{P}_{2} \mathrm{O}_{5}$ content of the Jacupiranga, Phalaborwa and Pallo samples are compared with Eppawela rock phosphate in the Table 1. Samples J and P are very similar to the Eppawela rock phosphate in their composition except in the silica contents. ${ }^{1}$ Samples $J$ and $P$ have higher silica contents than the Sri Lanka saimple. Comparison of powder X-ray diffraction patterns of pure synthetic chlor and fluorapatites ${ }^{3}$ with those of $\mathrm{J}$ and $\mathrm{P}$ samples revealed that the $\mathrm{J}$ and $\mathrm{P}$ contain fluorapatite, while Eppawela sample contains chlorfluorapatite. Sample $S$ gave a complex powder pattern completely different from the characteristic apatite pattern, indicating that it does not belong to apatite group of minerals. It has been reported ${ }^{7}$ that the $\mathrm{S}$ sample is from an aluminous phosphate deposit containing the minerals millisite, $\mathrm{NaCaAl}_{6}\left(\mathrm{PO}_{4}\right)_{4}(\mathrm{OH})_{9} \cdot 3 \mathrm{H}_{2} \mathrm{O}$, and crandalite, $(\mathrm{Ca}, \mathrm{Sr}$, $\mathrm{Pb})_{2} \mathrm{Al}_{7}\left(\mathrm{PO}_{4}\right)_{3}(\mathrm{OH})_{16} \cdot 3 \mathrm{H}_{2} \mathrm{O}$. According to analytical data the $\mathrm{S}$ sample contains as much as $10 \% \mathrm{Fe}_{2} \mathrm{O}_{3}$.

All three samples ( $\mathrm{J}, \mathrm{P}$ and $\mathrm{S}$ ) show very low content of available $\mathrm{P}_{2} \mathrm{O}_{5}$. Senegal sample shows the lowest value $(0.1)$ which can be explained on the basis of the nature of its constitutent minerals. Although $\mathrm{J}$ and $\mathrm{P}$ samples resemble the Sri Lanka sample in their structure and composition, these have very much lower solubilities (0.3 and 1.2 respectively) than the Sri Lanka sample (6.3). These data show that the $S$ sample is not at all suitable for 
direct application to plants. Similiarly, $J$ and $P$ samples would be very much less effective than the Sri Lanka sample for direct application to crops. The residues of $\mathrm{J}$ and $\mathrm{P}$ samples after $2 \%$ citric acid extraction were identified as fluorapatiite, while the residue of the $S$ sample could not be jdentified by powder X-ray diffraction.

TABle 1. Data on The Phosphate Rock Samples

\begin{tabular}{|c|c|c|c|c|}
\hline \multirow{2}{*}{ Rock sample } & \multicolumn{2}{|c|}{$2 \%$ Citric acid solubility } & \multirow{2}{*}{$\begin{array}{c}\text { Total } \mathrm{P}_{2} \mathrm{O}_{5} \text { content } \\
\mathrm{Wt} . \%\end{array}$} & \multirow{2}{*}{ X-ray identification } \\
\hline & $\bar{W} t . \quad \% \mathrm{P}_{2} \mathrm{O}_{5}$ & $\%$ of total $\mathrm{P}_{2} \mathrm{O}_{5}$ & & \\
\hline Eppawela & 6.3 & 17.0 & 38.1 & Chlorfluorapatite \\
\hline $\begin{array}{l}\text { Jacupiranga } \\
\text { (Brazil) }\end{array}$ & 0.3 & 0.9 & 35.1 & Fluorapatite \\
\hline $\begin{array}{l}\text { Pahalaborwa } \\
\text { (South Africa) }\end{array}$ & 1.2 & 3.3 & 36.2 & Flurorapatite \\
\hline $\begin{array}{l}\text { Pallo } \\
\text { Senegal) }\end{array}$ & 0.1 & 0.4 & 28.6 & Not an apatite \\
\hline
\end{tabular}

\subsubsection{Composition with sodo ash and quartz}

Table 2 presents the data on the batches made with the rock samples, soda ash and quartz. The compositions around the previously determined ${ }^{7}$ optinum molar ratio of rock phosphate : soda ash : cua:tz, 1:2:1, have been used in this study. Since J, P and S samples coniain relativeiy higher amounts of silica $(1-2 \%)$ than the Sri Lanka sample $(0.4 \%)$ compositions containing less silica than the 1:2:1 molar ratio have been investigated.

TABle 2. Data on Sinters Made with the Rock Samples (Temp. $950^{\circ} \mathrm{C}$, Duration. 2 Hrs.).

\begin{tabular}{|c|c|c|c|c|c|c|c|}
\hline \multicolumn{4}{|c|}{ Composition } & \multirow{2}{*}{\multicolumn{3}{|c|}{$\begin{array}{l}2 \% \text { citric acid } \\
\text { solubilicy of } \% \text { of } \\
\text { Wt. } \% \mathrm{P}_{2} \mathrm{O}_{5} \text { total } \mathrm{P}_{2} \mathrm{O}_{5}\end{array}$}} & \multirow[b]{2}{*}{ Phases present } \\
\hline $\begin{array}{l}\text { Molar ratio } \\
\text { Rock phos. } \mathrm{Na}_{2} \mathrm{CO}_{3}: \mathrm{SiO}\end{array}$ & 2 Rock & $\mathrm{Na}_{2} \mathrm{CO}_{3}$ & $\overline{\mathrm{SiO}_{2}}$ & & & & \\
\hline \multicolumn{8}{|l|}{ I rock sample } \\
\hline $1: 2: 0$ & 70.5 & 29.5 & 0.0 & 30.8 & & $.0 \beta-C$ & $\begin{aligned} \mathrm{CaNa}_{2} \mathrm{PO}_{4} & +\mathrm{CaNa}_{6} \mathrm{P}_{2} \mathrm{O}_{9} \\
& +\mathrm{CaO}\end{aligned}$ \\
\hline $\begin{array}{l}1: 2: 1 \\
4: 8: 3(\text { ie. } 1: 2: 0.75)\end{array}$ & $\begin{array}{l}65.1 \\
66.4\end{array}$ & $\begin{array}{l}27.2 \\
27.7\end{array}$ & $\begin{array}{l}7.7 \\
5.9\end{array}$ & $\begin{array}{l}28.4 \\
28.9\end{array}$ & $\begin{array}{l}100 . \\
100.0\end{array}$ & $\begin{array}{ll}0 & \alpha-0 \\
0 & \alpha-c\end{array}$ & $\begin{array}{l}\mathrm{CaNaPO} \mathrm{NaNa}_{4}+\mathrm{CaNa}_{6} \mathrm{P}_{2} \mathrm{O}_{9} \\
\mathrm{Ca}^{2} \mathrm{CaPO}_{4}+\mathrm{CaN}_{2} \mathrm{~F}_{2} \mathrm{O}_{9} \\
+ \text { tr. CaO }\end{array}$ \\
\hline $2: 4: 1$ (ie. $1: 2: 0.5)$ & 67.7 & 28.3 & 4.0 & 29.4 & 100. & $0 \alpha-C$ & $\begin{aligned} \mathrm{CaNaPO}_{4} & +\mathrm{CaNa}_{7} \mathrm{P}_{2} \mathrm{O}_{9} \\
& + \text { tr. CaO }\end{aligned}$ \\
\hline \multicolumn{8}{|l|}{ Prock sample } \\
\hline $1: 2: 0$ & 70.5 & 29.5 & 0.0 & 30.6 & 98.6 & $0 \alpha-C$ & $\begin{array}{l}\mathrm{CaNaPO}_{4}+\mathrm{CaNa}_{6} \mathrm{P}_{2} \mathrm{O}_{9} \\
+\mathrm{CaO}+\text { tr.Fllorapatite }\end{array}$ \\
\hline $1: 2: 1$ & 65.1 & 27.2 & 7.7 & 28.4 & 100. & $0 \alpha-C$ & $\mathrm{CaNaPO} \mathrm{CaNa}_{6} \mathrm{P}_{2} \mathrm{O}_{9}$ \\
\hline $4: 8: 3($ ie. $1: 2: 0.75)$ & 66.4 & 27.7 & 5.9 & 29.0 & 100. & $0 \quad \alpha-0$ & $\mathrm{CaNaPO}_{4}+\mathrm{CaNa}_{6} \mathrm{P}_{2} \mathrm{O}_{9}$ \\
\hline $2: 4: 1$ (ie. $1: 2: 0.5$ ) & 67.7 & 28.3 & 4.0 & 4.0 & 100. & $0 \alpha-C$ & $\begin{aligned} \mathrm{CaNaPO}_{4} & +\mathrm{CaNa}_{6} \mathrm{P}_{2} \mathrm{O}_{9} \\
+ & + \text { tr. } \mathrm{CaO}\end{aligned}$ \\
\hline \multicolumn{8}{|l|}{$S$ rock sample } \\
\hline $1: 2: 0$ & 69.6 & 30.4 & 0.0 & 12.0 & 41.9 & There & is reation. Products?? \\
\hline
\end{tabular}

Note. J,P and $\mathrm{S}$ samples are Jacupiranga, Phalaborwa and Pallo samples respectively. $t \mathrm{r} .=$ trace. 
For the $\mathrm{J}$ and $\mathrm{P}$ samples 1:2:0 molar ratio gave a yield of $98-99 \%$ available $\mathrm{P}_{2} \mathrm{O}_{5}$ at $950^{\circ} \mathrm{C}$ for 2 hours heating (Table 2). However, the yield of available $\mathrm{P}_{2} \mathrm{O}_{5}$ in the corresponding $\mathrm{S}$ sample was rather poor (about $42 \%$ ).

With Eppawela apatite it has been observed ${ }^{6}$ that mixtures of apatite and $\mathrm{Na}_{2} \mathrm{CO}_{3}$ react to produce lime as one of the products, in the absence of silica. In this study too it has been observed that the sintered product in the molar ratio $1: 2$ contains lime in addition to rhenanite, $\mathrm{CaNaPO}_{4}$ and $\mathrm{CaNa}_{6} \mathrm{P}_{2} \mathrm{O}_{9}$. A.s free lime is considere ${ }^{6}$ to be undesirable constituent in the product, silica has to be added to combine with it. A reaction was observed with the $1: 2$ composition of the $\mathrm{S}$ sample, but the product could not be identified. Furthermore, this product turned deep reddish brown in colour probably due to the presence of a large amount of iron.' In view of the poor available $\mathrm{P}_{2} \mathrm{O}_{5}$ content of this mixture it was decided not to proceed further with the sample $\mathrm{S}$.

Both molar ratios $1: 2: 1$ and $2: 4: 1$ with the samples $\mathrm{J}$ and $\mathrm{P}$ gave $100 \%$ yicld of available phosphorus at $950^{\circ} \mathrm{C}$ for 2 hours heating. However, in the composition 2:4:1 with both $J$ and $P$ samples, the products developed a trace of lime along with rhenanite and $\mathrm{CaNa}_{6} \mathrm{P}_{2} \mathrm{O}_{9} \cdot 2: 4: 1$ (i.e. $1: 2: 0.5$ ) composition was obtained by reducing the silica content by $50 \%$ from the optimum ratio $1: 2: 1$. At this stage, $25 \%$ reduction of the silica content was attempted by preparing the mixtures with the molar ratio $4: 8: 3$ (i.e. $1: 2: 0.75$ ) using the $\mathrm{J}$ and $\mathrm{P}$ samples. 4:8:3 composition with the $\mathrm{J}$ sample gave a trace of lime while the corresponding composition with the P sample did not yield any trace of free lime. Therefore, these results indicate that the optimum ratio of the rock: $\mathrm{Na}_{2} \mathrm{CO}_{3}: \mathrm{SiO}_{2}$ lies very close to $1: 2: 1$ in the case of $J$ sample while in the $\mathrm{P}$ rock sample the silica content may be further reduced by $25 \%$. It is of interest to note that $\mathrm{CaNa}_{6} \mathrm{P}_{2} \mathrm{O}_{9}$ persists in $1: 2: 1,2: 4: 1$ and $4: 8: 3$ compositions of the $J$ and $P$ at $950^{\circ} \mathrm{C}$. However, the corresponding compositions with the Eppawela apatite gave rhenanite, $\mathrm{CaNaPO}_{4}$ as the only sodium containing phase. On the basis of phase equilibrium data, ${ }^{7} \mathrm{CaNa}_{6} \mathrm{P}_{2} \mathrm{O}_{9}$ is not a. stable phase in this part of the system and therefore its occurrence is protably metastable. Nevertheless, the total phosphorus content in $\mathrm{CaNa}_{6} \mathrm{P}_{2} \mathrm{O}_{9}$ is soluble $e^{7}$ in $2 \%$ citric acid solution and therefore it is considered as a desirable phase in the final product.

\subsection{Experiments with Eppawela appatite}

\subsubsection{Replacement of quartz ly feldspor}

The replacement of quartz by local potash feldspar in the composition would lead to a product containing two additional constituents, $\mathrm{K}_{2} \mathrm{O}$ and $\mathrm{Al}_{2} \mathrm{O}_{3}$. The presence of potash in the product would be an additional advantage because polassium is an important plant nutrient. As such, replacement of quartz by potash feldspar has been investigated in this study. 
The molar ratio of apatite, soda ash and potash feldspat ( $\mathrm{KAlSi}_{3} \mathrm{O}_{8}$ ), 6:11:2 respectively, has been calculated to be equivalent to the optimum ratio of apatite, $\mathrm{Na}_{2} \mathrm{CO}_{3}$ and quartz, 1:2:1. Both 6:11:2 composition with feldspar and $1: 2: 1$ composition with quartz were heated at $900^{\circ} \mathrm{C}$ for 2 hous in a muffle funace, and the products were subsequently analysed for available $\mathrm{P}_{2} \mathrm{O}_{5} .97 \%$ of the total $\mathrm{P}_{2} \mathrm{O}_{5}$ was found to be converted to the available form in the composition, $1: 2: 1$ (with quartz) while only $86 \%$ conversion was observed in the equivalent composition with feldspar. However, when heating time was increased to 12 hours, $100 \%$ conversion was observed in the composition with feldspar. The $\mathrm{K}_{2} \mathrm{O}$ content of this product was estimated to be $1.9 \%$ wt. by Flame Photometry.

The results indicate that silica may be replaced by potash feldspar in this method to obtain potassium containing phosphorus fertilizer. The rate of reaction appears to be slow with feldspar, and if feldspar were to be used instead of quartz, duration of heating should be increased to about 12 hours.

\subsubsection{Dynamic heating experiments}

The samples having the molar ratio of Eppawela apatite, soda ash and quartz $1: 2: 1$, were heated in a mufle furnace from ambient to $950^{\circ} \mathrm{C}$ at a teating rate of $5^{\circ} \mathrm{C} \mathrm{min}^{-1}$. Over the temperature range $550^{\circ} \mathrm{C}$ to $950^{\circ} \mathrm{C}$, samples were removed at $50^{\circ} \mathrm{C}$ intervals and cocled rapidly in air. The solubility data and $\mathrm{X}$-ray analysis of the produats are recorded in Table 3.

Table 3. Dyramic Heating Results

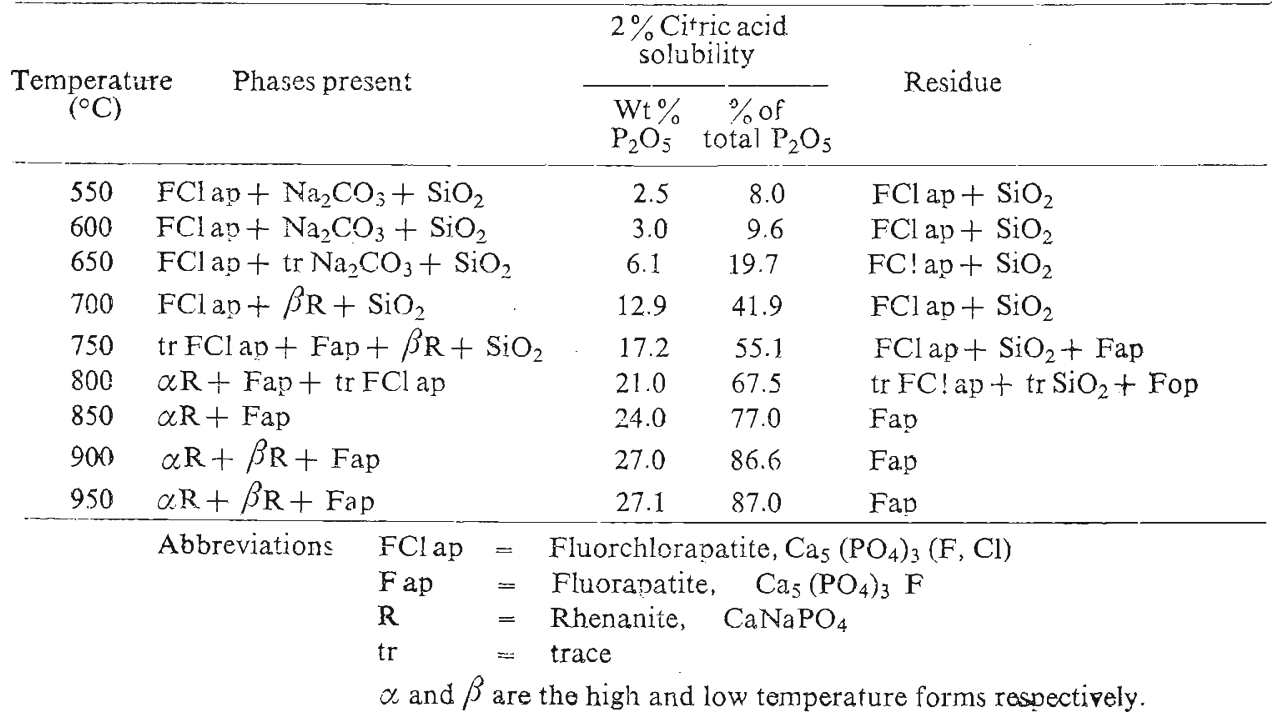


At temperatures less than $600^{\circ} \mathrm{C}$, the percentage $\mathrm{P}_{2} \mathrm{O}_{5}$ is essentially equal to that which would be extractable from the quantity of ground mineral apatite fraction contained in the batch: heat treatment makes no difference. At temperatures above $600^{\circ} \mathrm{C}$ the percentage $\mathrm{P}_{2} \mathrm{O}_{5}$ rises, reaching the highest value around $900^{\circ} \mathrm{C}$, confirming that $900^{\circ} \mathrm{C}$ is the optimum temperature for this process.

Temperatures around $900^{\circ} \mathrm{C}$ were found to be critical by heating a sample in a muffic furnace from ambient to $850^{\circ} \mathrm{C}$ at $5^{\circ} \mathrm{C}$ min ${ }^{-1}$, then subsequently holding the sample at this temperature for 2 hours. The percentage yield of $\mathrm{P}_{2} \mathrm{O}_{5}$ out of the total $\mathrm{P}_{2} \mathrm{O}_{5}$ content was found to be $88 \%$, considerably lowr than that obtained when the exteriment was repeated, heating at the same rate to $900^{\circ} \mathrm{C}$ and holding at $900^{\circ} \mathrm{C}$ for 2 hours, in which case the yield obtained rose to $96 \%$.

\subsubsection{Heating Experiments in Controlled Atmospheres}

The effect of furnace atmosphere on the reaction of Eppawela apatite with soda ash and quartz was studied by using a Tube Furnace with two tubes in different atmospheres. Carbon dioxide was used as one atmosphere while the 'control' atmospheie was air. The samples were raced in the tube furnace and heated from ambient to $900^{\circ} \mathrm{C}$ in 45 minutes and mainained at $900^{\circ} \mathrm{C}$ for 2 hours. After heat treatment, the samples were removed from the furnace, cooled rapidly to ambient and used for subsequent analysis. The experiments were repeated with Jacupiranga and Phalaborwa rock samples and the results are given in Table 4.

TABle 4. Effect Of Furnace Atmosphere On The Reaction at $900^{\circ} \mathrm{C}$

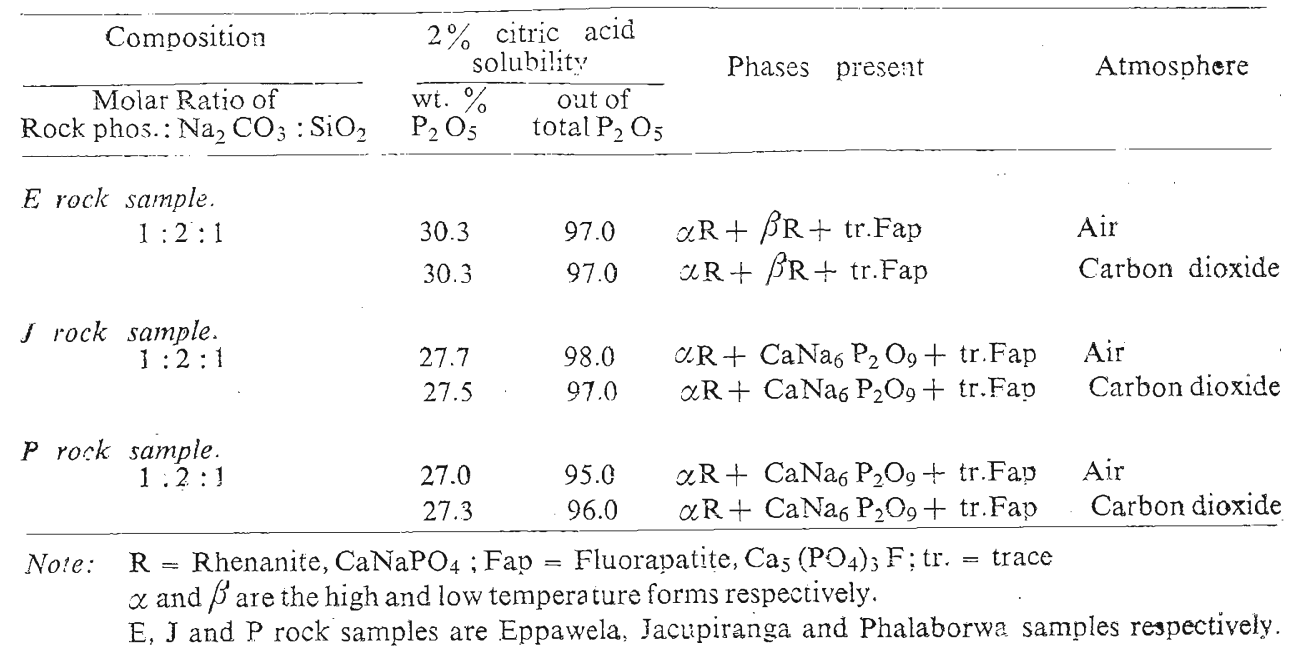


Table 4 shows that almost similar values of available $\mathrm{P}_{2} \mathrm{O}_{5}$ are obtained in two different fumace atmospheres with Eppawela apatite as well as with. the other two rock samples. Thus, it is apparent that the yicld of $\mathrm{P}_{2} \mathrm{O}_{5}$ is insensitive to the partial pressure of $\mathrm{CO}_{2}$, but temperatures arcund $900^{\circ} \mathrm{C}$ arc critical with respect to the yield obtained.

\subsubsection{Differential Thermal Analysis}

Differential Thermal Analyses were carried out on samples containing

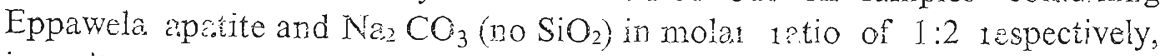
in a nitrogen atmosphere upto $1000^{\circ} \mathrm{C}$. No $\mathrm{Na}_{2} \mathrm{CO}_{3}$ meling endotherm was observed but a broad area of thermal activity ocrurred in both examples which were studicd. This broad area appeared to be characteristic of mixtures not containing $\mathrm{SiO}_{2}$. The rhases present after thermal analysis were $\alpha$ and $\beta$ Rhenanite, $\mathrm{CaO}$ and residual fluorapa'ite.

Similar analyses were performed on samples containing Eppawela apatite, $\mathrm{Na}_{2} \mathrm{CO}_{3}$ and $\mathrm{SiO}_{2}$ in the molar $\mathrm{ratio} 1: 2: 1$, in a $\mathrm{N}$ or $\mathrm{CO}_{2}$ atmosphere to a maximum temperature of $1000^{\circ} \mathrm{C}$. The high-low guartzinversion, ${ }^{4}$ at $573^{\circ} \mathrm{C}$ was used as an internal sandard: however, the portion of the trace below $600^{\circ} \mathrm{C}$ has been omitted from Figure 1. The reaction mixture showed no melting endotherm at $851^{\circ} \mathrm{C}$, the temperature at which pure $\mathrm{Na}_{2} \mathrm{CO}_{3}$ melts, but a broad area of thermal activity occurred over the temperature rarge $6 \varepsilon 0^{\circ} \mathrm{C}-870^{\circ} \mathrm{C}$. This is depicted in Figure 1 ; the phases present after analysis were $\alpha$ and $\beta$ Khenanite and fluorapatite. Thermal activity begins at a slightly higher temperature in a $\mathrm{CO}_{2}$ atmosphere, as might be expected if reaction leading to endothermic activity were initiated by loss of $\mathrm{CO}_{2}$. In both cases the region of thermal activity consists of two steps, although these two regions are more pronounced when a $\mathrm{CO}_{2}$ atmosphere is used than in $\mathrm{N}$, but are never completely resolved from each other.

The arca of thermal activity can be accounted for by three events. Firstly with increasing temperature, the loss of $\mathrm{CO}_{2}$ occurs over a wide range of temperature. At $\sim 760^{\circ} \mathrm{C}, \mathrm{CaNaPO}_{4}$ (rhenanite) one of the reaction products, undergoes an inversion ${ }^{2}$ thereby producing the first relatively sharp endotherm. At $\sim 820^{\circ} \mathrm{C}$, a small amount of melting may occur resulting in more rapid elimination of $\mathrm{CO}_{2}$, thereby producing the second endotherm. The lack of a melting endotherm at $851^{\circ} \mathrm{C}$, coupled with the elimination of much $\mathrm{CO}_{2}$ below $850^{\circ} \mathrm{C}$, indicated that most of the $\mathrm{Na}_{2} \mathrm{CO}_{3}$ must have reacted before its melting point is reached. The sintered. appearance of mixtures after firing stggested the possible existence of a transient liquid phase at some point during the reaction. However, DTA indicates that liquid, if present, must form only as a quantitatively minor phase. 


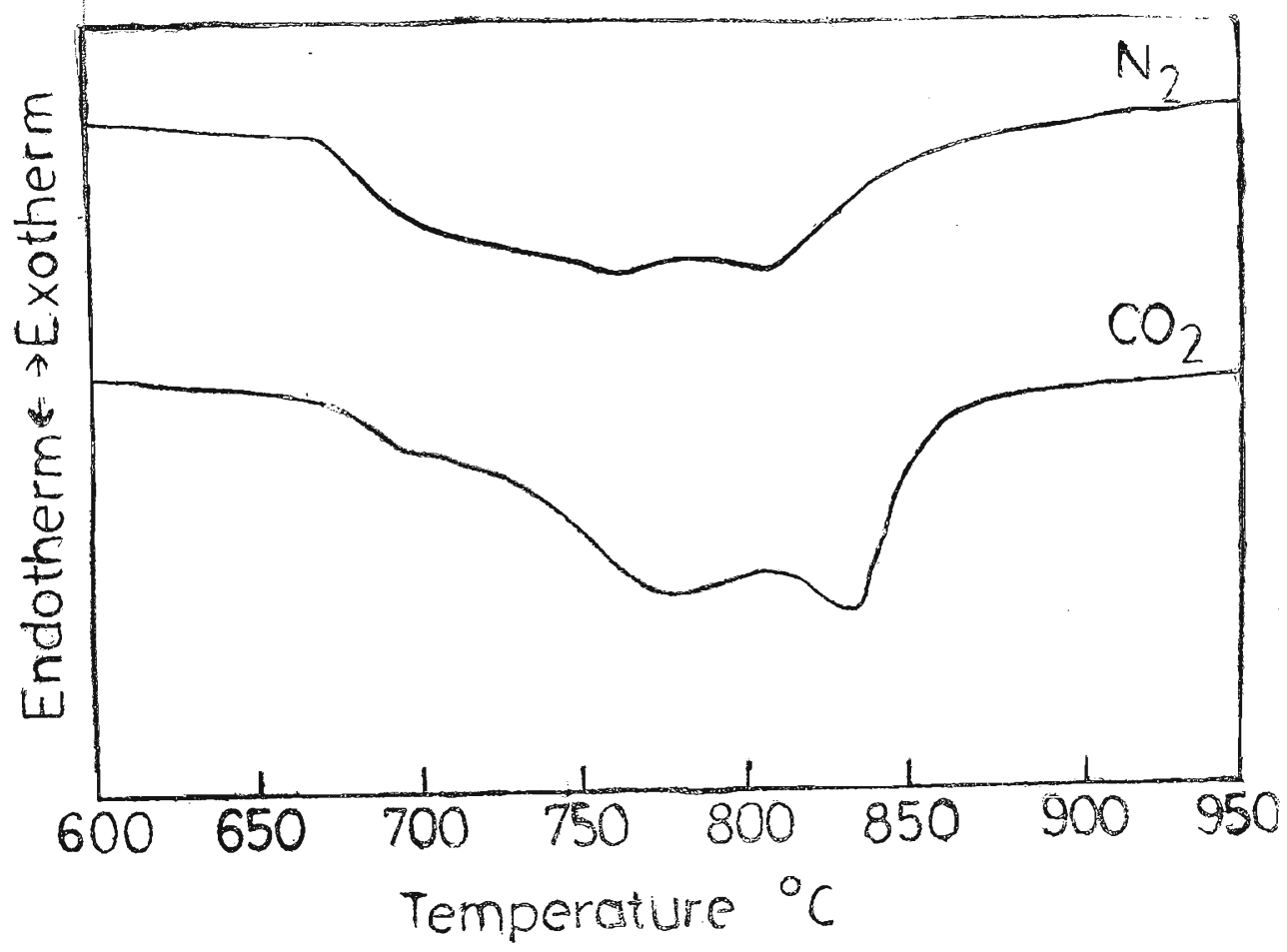

Figure 1. DTA curves in $\mathrm{N}$ and $\mathrm{CO}_{2}$ atmospheres during heating of apatite, $\mathrm{Na}_{2} \mathrm{CO}_{3}$ and quartz in molar ratio $1: 2: 1$ respectively.

\subsubsection{Thermogravimetric Analysis}

Thermogravimetric analyses were carried out on samples having the molar ratio of Eppawela apatite, soda ash and quartz, $1: 2: 1$, respectively, by heating them from ambient to $1000^{\circ} \mathrm{C}$ in an atmosphere of $\mathrm{N}$ or $\mathrm{CO}_{2}$ at various heating ratis. The flow of gas was kept sufficiently high (a out $100 \mathrm{cc} / \mathrm{min}$ ) to flush away any gases evolved from the sample.

The theoretical \% weight loss is $13.5 \%$ and the results obtained using $\mathrm{N}$ atmosphere are slightly greater than the theoretical value. However, the weight losses at heating rates, $15^{\circ} \mathrm{C} \mathrm{min}-1(13.6 \%)$ and $20^{\circ} \mathrm{C} \mathrm{min-1}$ $(13.8 \%)$ are approximately equal to the theoretical value. At the slower heating rate of $5^{\circ} \mathrm{C} \mathrm{min}^{-1}$, a weight loss of $14.3 \%$ was observed and the increase in weight loss here may also be due to the liberation of some halogen from apatite. The percentage weight loss ising a $\mathrm{CO}_{2}$ atmosphere is significantly lower $(10.3 \%)$ than the theoretical value. If the extent of the reaction is equated to weight loss, it appears on this basis that the reaction here is incomplete. Furthermore, the results indicate that under the conditions of ther mogravimetric analysis, the weight loss which is mainly due to the liberation of $\mathrm{CO}_{2}$ 
is aignificantly lowered in a $\mathrm{CO}_{2}$ atmosphere. However, this value $(10.3 \%)$ was obtained using a very fast heating rate $\left(15^{\circ} \mathrm{C} \mathrm{min}^{-1}\right)$ and therefore it is also possible that with slower heating rates the losses would approach theoretical.

The effect of varying the atmosphere while heating samples at the same rate is shown in Figure 2(a). Weight loss is more rapid in a $\mathrm{N}$ atmosphere, and the final percentage weight loss is significantly larger than in a $\mathrm{CO}_{2}$ atmosphere. The effect of varying the heating rate while heating the samples in the same controlled $\mathrm{N}$ atmosphere is shown in Figure $2(b)$. Weight loss occurred at lower temperatures in the sample heated at $5^{\circ} \mathrm{C} \mathrm{min}^{-1}$ than in that heated at $20^{\circ} \mathrm{C} \mathrm{min}^{-1}$. The final percentage weight loss is found to be greater when the sample is heated at the slower heating rate.

The slopes of the weight loss curves suggest that they can be divided into several regions, as shown in Figure 2 . Those regions of the curves having a marked change in gradient are marked $A B$ and $C D$. This indicates that weight loss proceeds in at least two steps, although these are not clearly resolved from each other. In the initial stage (around $650^{\circ}-750^{\circ} \mathrm{C}$ ) the loss of weight is slow, and at this stage it is expected that the volatile components are gradually lost and the decomposition of carbonates would commence. In the next stage (around $750^{\circ}$ to $900^{\circ} \mathrm{C}$ ) the loss is fairly rapid and this is probably due to the complete breakdown of carbonate followed by partial volatilization of fluorine.

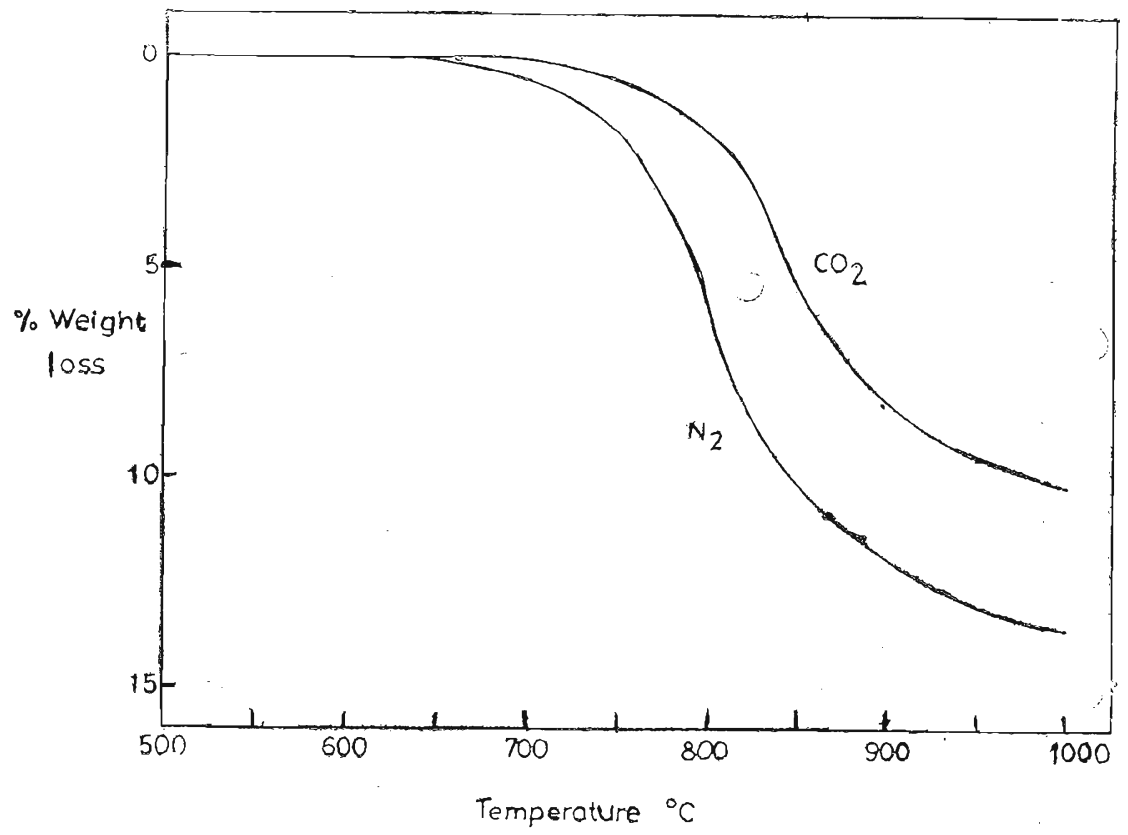

Figure $2(a)$ Weight loss curves obtained using TGA in $\mathrm{CO}_{2}$ and $\mathrm{N}$ atmospheres at the same heating rate. 


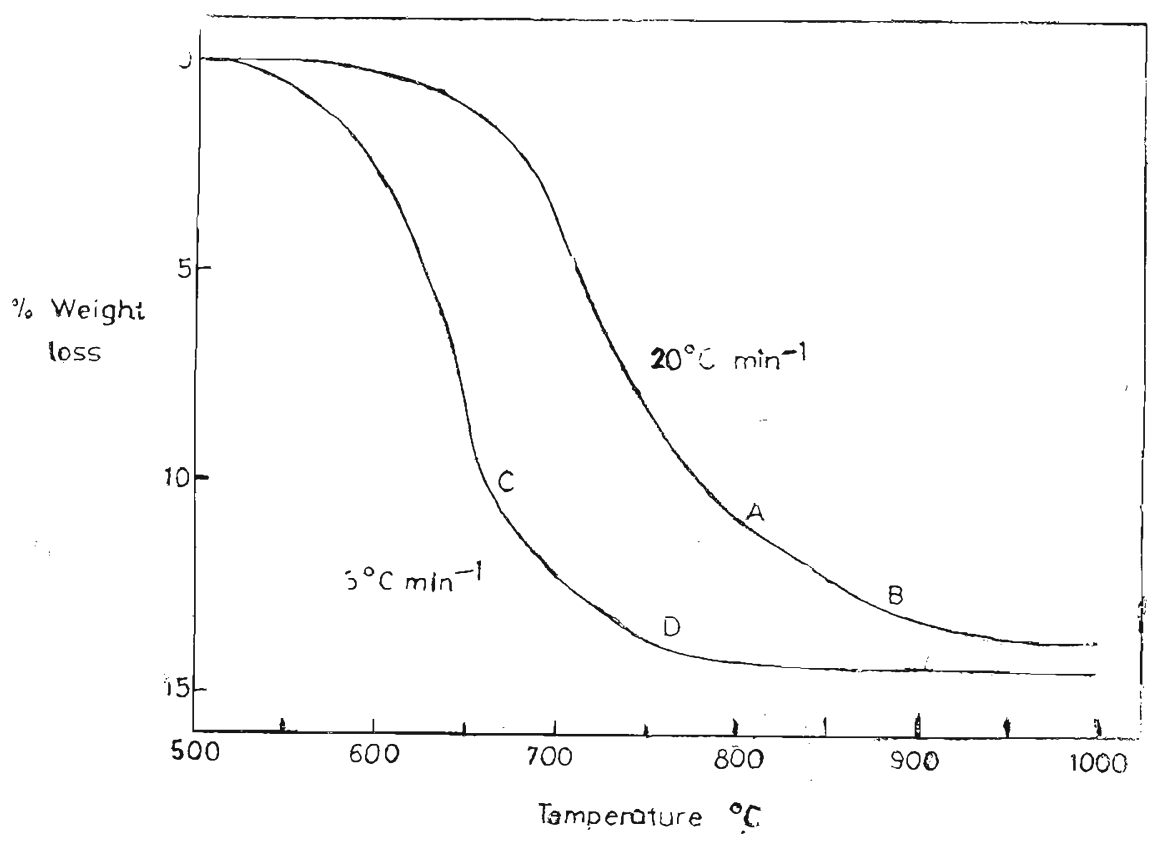

Figute 2 (b) Weight loss curves obtained using TGA, in $\mathrm{N}_{2}$ atmosphere at the heating rates of $5^{\circ} \mathrm{C} \mathrm{min}^{-1}$ and $20^{\circ} \mathrm{C} \mathrm{min}^{-1}$.

\subsubsection{Chloride ion exchange}

It has been observed ${ }^{5}$ that in sinters made with Eppawela apatite, $\mathrm{Na}_{2} \mathrm{CO}_{3}$ and quartz, about $68-85 \%$ of total fluorine is retained even at $1100^{\circ} \mathrm{C}$. Fluorine is not present as simple $\mathrm{F}^{-}$, but it is believed to be in the form of complex fluorosilicates. It has also been reported that under certain conditions fluorine in apatite may act as a flux ${ }^{9}$ thereby facilitating the conversion of apatite to a more soluble form.

The fate of chlorine during the reaction has been investigated in the present study by heating samples of Eppawela apatite, $\mathrm{Na}_{2} \mathrm{CO}_{3}$ and quartz in the molar ratio, 1:2:1 respectively, in a muffle furnace at a heating rate of $5^{\circ} \mathrm{C}$ $\min ^{-1}$ to various intermediate reaction temperatures up to $900^{\circ} \mathrm{C}$. In addition, two more samples were heated at $900^{\circ} \mathrm{C}$ and $1100^{\circ} \mathrm{C}$ for a period of 2 hours. A $1.0 \mathrm{~g}$ sample of these sinters was then shaken with $50 \mathrm{ml}$ of de-ionized water for $30 \mathrm{~min}$. The solution was filtered to remove insoluble residue, neutralized using nitric acid, and the water soluble chloride content determined by titrating with a standard $\mathrm{AgNO}_{3}$ solution to a potentiometric endpoint. The results of these analyses are given in Table 5 . 
TABI.E 5. Solutle Chloride at different temperatures

\begin{tabular}{ccc}
$\begin{array}{c}\text { Temperature } \\
\text { C (heating rate } \\
\left.5^{\circ} \mathrm{C} / \mathrm{min}\right)\end{array}$ & $\begin{array}{c}\text { Solublert- } \\
\text { in mg/1g sanjple }\end{array}$ & $\%$ Soluble $\mathrm{Cl}^{-}$ \\
\hline unfired & 0.2 & .0 .02 \\
550 & 0.9 & 0.09 \\
600 & 1.3 & 0.13 \\
650 & 2.6 & 0.26 \\
700 & 7.5 & 0.75 \\
750 & 12.5 & 1.25 \\
800 & 12.6 & 1.26 \\
850 & 12.3 & 1.23 \\
900 & 10.3 & 1.03 \\
900,2 hrs. & 8.2 & 0.82 \\
1100,2 hrs. & 0.3 & 0.03 \\
\hline
\end{tabular}

Note: Apatite sample used in this studyr contained $2.2 \%$ wt. $\mathrm{Cl}$.

If all the chloride present in apatite were to dissolve, $1 \mathrm{~g}$ sample of the product (assuming that the reaction. is complete and all $\mathrm{CO}_{2}$ lost) should contain $16.2 \mathrm{mg}$ of soluble chloride. On heating, soluble chloride level increases rapidly above $600^{\circ} \mathrm{C}$, rising to a maximum at $750^{\circ} \mathrm{C}-800^{\circ} \mathrm{C}$ and then decrease with increase in temperature. In the temperature range $750^{\circ}-800^{\circ} \mathrm{C}$ almost $75 \%$ of the total chloride content is in the soluble form. At $900^{\circ} \mathrm{C}$ after 2 hours, soluble chloride content is reduced to $50 \%$, while 2 hours heating at $1110^{\circ} \mathrm{C}$ reduced it to the level of unfired sample.

Thus, these analyses indicate that apatite participates in an ion exchange process during early stages of the reaction and that much of the chloride thus liberated is present in water soluble form. However, at temperatures higher than $900^{\circ} \mathrm{C}$ chlorine is rapidly lost from the samples.

In apatite, each calcium atom is bonded to neighbours above and below by means of three shared oxygen atoms, thus forming vertical chains of alternate calcium and oxygen atoms. The vertical columns are also linked to phosphate groups to form a hexagonal framework. This results in a honeycomb structure ${ }^{10}, 11$ having channels parallel to the $\mathrm{C}$ axis, and the negatively charged halide ions are positioned within these channels.

During the reaction it is apparent that the chloride ions are withdrawn selectively from apatite. After some of the apatite has reacted, the remaining apatite has unit cell dimensions similar to that of fluorapatite. In all the hecting experiments, the cell dimensions of residual apatite had changed to those characteristic of fluorapatite. This observation coupled with the appearance of chloride ion during intermediate stages of reaction confirm the occurrence of ion exchange in apatite prior to extensive attack leading to its conversion to thenanite, etc. 
It is difficult to postulate how the apatite maintains its charge balance during the suggested ion exchange process. One possibility is that charge balance is maintained by replacing $2 \mathrm{Cl}^{-}$by $2(\mathrm{OH})^{-}, \mathrm{O}_{2}^{-}$or a mixture of the two. Hydroxyapatite $^{8}$ is known to have cell dimensions very similar to those of fluorapatite, but the cell dimensions of oxyapatite are not known.

\section{Conclusions}

The three rock samples Jacupiranga (Brazil), Phalaborwa (South Africa) and Pallo (Senegal) have very low available $\mathrm{P}_{2} \mathrm{O}_{5}$ contents and therefore, it is apparent that these samples may not be suitable for direct application to plants. In view of the low $\mathrm{P}_{2} \mathrm{O}_{5}$ content of the sintered product, Pallo sample is considered not suitable for the process. As in the case of Eppawela apatite, the molar ratio of $1: 2: 1$ is most suited for the Jacupiranga sample, while a further reduction of silica content, by $25 \%$, can be achieved with the Phalaborwa sample.

Potash containing phosphorus fertilize can be made using this process by replacing quartz by potash feldspar. At $900^{\circ} \mathrm{C}$ the reaction appear to be slow but with increased reaction time, high percentage yield of $\mathrm{P}_{2} \mathrm{O}_{5}$ could be obtained.

Dynamic heating experiments confirmed that the optimum temperature for the reaction is around $900^{\circ} \mathrm{C}$ and a further reduction of temperature cannot be achieved without seriously affecing the yield of available $\mathrm{P}_{2} \mathrm{O}_{5}$. Partial pressure of $\mathrm{CO}_{2}$ was found to have a minimal effect on the available phosphorus content of the product.

During the reaction much of the $\mathrm{CO}_{2}$ is liberated before the melting point of pure $\mathrm{Na}_{2} \mathrm{CO}_{3}$ is reached. Formation of a transient liquid phase would facilitate the sintering reaction. The weight loss occurs in two stages during the reaction. Initial loss is gradual and is due to the slow decomposition of the carbonate while the loss is much greater at higher temperatures $\left(800^{\circ}\right.$ to $\left.900^{\circ} \mathrm{C}\right)$ owing to the rapid decomposition of carbonates followed by the loss of some halogen.

Chlorine in apatite undergoes extensive ion exchange prior to the sintering reaction. Available evidence indicates that chloride is exchanged for hydroxyl and /or oxide ions before commencement of decomposition.

\section{Acknowledgment.}

A part of this work was done at the University of Aberdeen, U.K. by the author with the financial support from the National Research Development Corporation (NRDC) of London. I wish to thank Dr. F.P. Glasser of the Department of Chemistry, University of Aberdeen for his assistance in the high temperature experiments and Mr. Jim Mair of the same Department for DTA analyses. The author is also grateful to the International Foundation for Science, Sweden, for an equipment grant. 


\section{Refer ences}

1. Bennet, F. W. (1981). A Selection of possibly suitable phosphate materials for consideration in assessing the applicability of the Glasser modified Rhenania process. A report submitted to the National Research Development Corporation, London, U.K.

2. Bredig, M. A. (1942). J. Phys. Chem. 46: 747.

3. Corbridge, D. E. C. (1974) The Structural Chemistry of Phosphorus, Elsevier Publishing Company, Amsterdam. London, New York.

4. FenNeR, C. M. (1913) Am. J. Sci., $36: 331$.

5. Gunawardane, R. P. (1979) Proc. Sri Lanka Assoc. Adv. Sci. $35: 56$.

6. Gunawardane, R. P. (1979) Proc. Sri Lanka Assoc. Adv. Sci. 35 : 56-57.

7. Gunawardane, R. P. \& Glasser, F. P. (1979) J. Mater. Sci. $14: 2797$ - 2810.

8. Hendrics, S. B., Jefferson, M. E. \& Mosley, V. M. (1932) Zeitschrift fur Kristallographie $81: 353-369$.

9. Jeffery, P. G. (1971) Chemical Methods of Rock Analysis, Pergamon Press, Oxford.

10. MeHmel, M. (1930) Zeitschrift fur Kristallographie, $75: 323$.

11. NAREY-SzaBo, S. (1930) Zeitschrift fur Kristallographie, $75: 387$.

12. Pierre, W. H. \& Norman, A. G. (1953) Soil and Fertiliz?r Phosphorus in Crop Nutrition Academic Press, London, New York. 